\title{
Research on the Shift Strategy for the Traction Vehicle with Automatic Transmission
}

\author{
Zhou Jing $^{1}$ \\ ${ }^{1}$ Beijing Institute of Technology, Zhuhai \\ Zhuhai city, Guangdong province, China
}

\begin{abstract}
Firstly, according to the working characteristic diagram of engine and hydraulic torque converter, the matching working point is found. On this basis, the theoretical model of gear shifting law is derived when the engine and the hydraulic torque converter work together by taking the acceleration of adjacent two gears equal as the shift point. Finally, the theoretical model is simulated, the shift pattern diagram of tractor automatic transmission is obtained and the shift pattern diagram is analyzed, and the results are of important reference value for further study of shift delay and other characteristics.
\end{abstract}

\section{INTRODUCTION}

In order to give full play to the power of the engine, the development trend at home and abroad is to adopt the multi-gear box and electronic control technology in the transmission system to improve the economic and dynamic performance of the engineering vehicle transmission system. Due to the low speed, heavy load and rapid change of load of engineering vehicles under operating conditions, which are different from the use of automobiles, it is not suitable to use the latch-clutch to solve the problem of low transmission efficiency of hydraulic converter[1]. Therefore, it is necessary to seek a new gear shifting strategy to solve the low transmission efficiency of hydraulic torque converter in engineering vehicles. Figure 1 summarizes how to use the characteristic curves of engine and hydraulic converter working together to determine their operating point.

Shifting rule refers to the rule of automatic shifting between two gears changing with control parameters, which is one of the key technologies of automatic transmission. The development of automatic transmission shift rule has gone through three stages: single parameter, two parameters, dynamic three parameters shift rule. At present, the research of automatic transmission vehicle shift rule generally adopts two parameters shift rule[2].

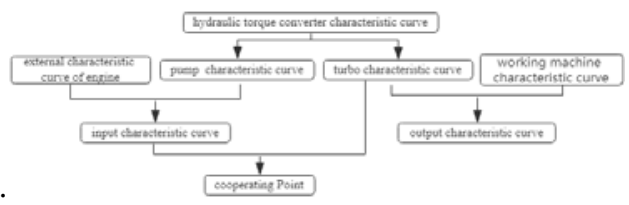

Figure 1. Determine the common operating point of engine and hydraulic torque converter

\section{Calculation of Engine and Torque CONVERTER MATCHING CHARACTERISTIC}

\subsection{Engine Performance Characteristics}

At present, gasoline engine or diesel engine is widely used in vehicle power plant, the performance of these engines, usually expressed in terms of engine power( $\left.P_{f}\right)$, torque $\left(T_{f}\right)$, and fuel consumption per hour $\left(G_{T}\right)$ as a function of engine speed, is a speed characteristic.

\subsection{Original Characteristics of Hydraulic Torque Converter}

The original characteristics of hydraulic torque converter refer to the relationship that torque coefficient, torque ratio and efficiency change with speed ratio. The original characteristics can accurately represent the basic performance of a series of hydraulic torque converters at different speeds.

\subsection{Input Characteristics for Working Together}

The common input characteristics of the engine and the hydraulic torque converter refer to the variation characteristics of the torque and the speed of the hydraulic torque converter and the engine working together at different speed ratios of the hydraulic torque converter. This is the basis for studying their matching, as well as the characteristics of the common input. When the engine is combined with the hydraulic torque 
converter, it can only work together stably if the speed and torque are equal, as shown below:

$$
\begin{aligned}
T_{B}= & T_{f} \times i_{q} \\
n_{f} & =i_{q} \times n_{B}
\end{aligned}
$$

\subsection{0utput Characteristics for Working Together}

The output characteristics of the engine and the hydraulic converter working together refer to the curves of output torque $\left(T_{T}\right)$, power $\left(P_{T}\right)$, engine fuel consumption $\left(G_{T}\right)$, specific fuel consumption $\left(g_{T}\right)$ and engine $\operatorname{speed}\left(n_{f}\right)$ changing with the turbine output shaft speed of the hydraulic converter.

$$
\begin{aligned}
& n_{T}=i \times n_{B} \\
& T_{T}=K \times T_{B} \\
& P_{T}=\frac{T_{T} \times n_{T}}{9555}
\end{aligned}
$$

$n_{T}, T_{T}$ and $P_{T}$ are respectively the rotational speed, torque and power of the turbo shaft; $n_{B}$ and $T_{B}$ are pump speed and torque;

$i, k$ and $\eta$ are respectively the speed ratio, torque coefficient and efficiency of the hydraulic torque converter.

\section{Theoretical Derivation of Gear SHIFTING RULES}

The relationship between the speed of the vehicle's driving equations is described in literature [3][4]. According to the requirements of trafficability characteristic and stability, the acceleration before and after the ideal shift is the same, Let's say the speed of the car in gear $\mathrm{n}$ is $v_{n}$, the speed is $v_{n+1}$ when you switch to the gear $(n+1)$, and the speed is equal before and after shifting with the road flat.

$$
\frac{d v_{n}}{d_{t}}=a_{n}=a_{n+1}=\frac{d v_{n+1}}{d t}
$$

$$
\frac{T_{T} \eta i_{o} i_{g}(n)}{R}=f m g \cos \theta+m g \sin \theta+\frac{C_{D} A}{21.15} v^{2}+\delta m a
$$

$$
\delta m a=\frac{T_{T} \eta i_{o} i_{g}(n)}{R}-\frac{C_{D} A}{21.15} v^{2}-m g(f \cos \theta+\sin \theta)
$$

$$
\begin{aligned}
& \frac{\frac{T_{T} \eta i_{o} i_{g}(n)}{R}-\frac{C_{D} A}{21.15} v_{n}{ }^{2}-m g(f \cos \theta+\sin \theta)}{\delta_{n} m}= \\
& \frac{\frac{T_{T} \eta i_{o} i_{g}(n)}{R}-\frac{C_{D} A}{21.15} v_{n+1}{ }^{2}-m g(f \cos \theta+\sin \theta)}{\delta_{n+1} m}
\end{aligned}
$$

$$
\frac{T_{T} \eta i_{o}}{R}\left[\delta_{n+1} i_{g}(n)-\delta_{n} i_{g}(n+1)\right]+\left[\frac{C_{D} A}{21.15} v^{2}+m g(f+\theta)\right]\left(\delta_{n}-\delta_{n+1}\right)=0
$$

According to the relationship between engine speed and vehicle speed at the operating point working together:

$$
v=0.377 \frac{n R i}{i_{o} i_{g}}
$$

In this formula, $i$ is the speed ratio of the hydraulic torque converter. While the output torque of the engine $(T)$ is a function of throttle opening $(\alpha)$ and engine $\operatorname{speed}(n)$, so $T=f(\alpha, n)$, substitute (eq.11) in and you get:

$$
T=f(\alpha, v)
$$

Substitute (eq. 12) into (eq. 10) and rearrange to obtain the function between $\operatorname{speed}(v)$ and throttle opening $(\alpha)$.

$$
v=f(\alpha)
$$

\section{Calculation Example}

A tractor adopts CA4D32TC engine and YJH265(high energy capacity) hydraulic torque converter, This tractor is taken as an example to calculate.

\subsection{Engine Characteristic Curve}

The original data of CA4D32TC engine performance test are shown in table 1 .

TABLE I. THE ORIGINAL TEST DATA OF CA4D32TC ENGINE PERFORMANCE

\begin{tabular}{ccc}
\hline $\begin{array}{c}\text { Engine speed } \\
n(r / \mathrm{min})\end{array}$ & $\begin{array}{c}\text { Torque } \\
M_{e}(N \cdot m)\end{array}$ & $\begin{array}{c}\text { Fuel consumption } \\
(\mathrm{kg} / \mathrm{h})\end{array}$ \\
\hline 1200 & 200 & 2 \\
1600 & 260 & 6.5 \\
2000 & 275 & 8 \\
2400 & 265 & 14 \\
3200 & 250 & 19 \\
\hline
\end{tabular}

\subsection{Characteristics of YJH265 Hydraulic Torque Converter}

The test characteristics of YJH265 hydraulic torque converter are shown in table 2.

TABLE II. TEST DATA OF YJH265 HYDRAULIC TORQUE
CONVERTER

\begin{tabular}{cccc}
\hline $\mathrm{i}$ & $\begin{array}{c}M_{b g} \\
(\mathrm{~N} \cdot \mathrm{m})\end{array}$ & $\mathrm{k}$ & $\eta$ \\
\hline 0 & 36 & 3.1 & 0 \\
0.3 & 38.5 & 2 & 0.6 \\
0.65 & 32 & 1.2 & 0.79 \\
0.8 & 24.6 & 1 & 0.8 \\
0.92 & 13 & 0.93 & 0.8556 \\
0.98 & 2 & 0.84 & 0.8232 \\
\hline
\end{tabular}


The characteristic curve fitting equation of engine and hydraulic torque converter is expressed in the same coordinate by MATLAB software[5], then the input characteristic curve for working together is obtained. The characteristic curve obtained from the original data of the engine is the curve when the throttle opening is $100 \%$, the curves of the engine at different throttle openings are also listed.

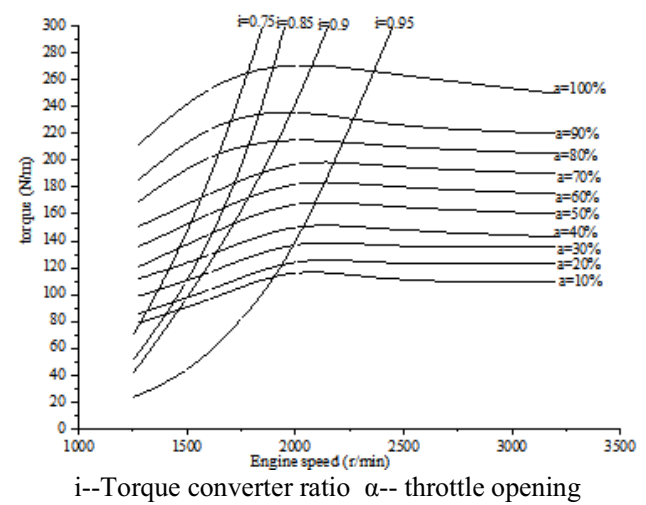

Figure 2. input characteristics of engine and torque converter working together

\subsection{Determination of Output Characteristics of Engine and Hydraulic Torque Converter Working Together}

When the torque converter speed ratio is between 0.75 and 0.95 , the engine is in the high efficiency zone. Therefore, in order to make the tractor obtain good power performance and economy, the output characteristics of the joint work must be within the efficient working range to obtain the highest average output power. The resulting output characteristics of the joint work are shown in figure 3 .

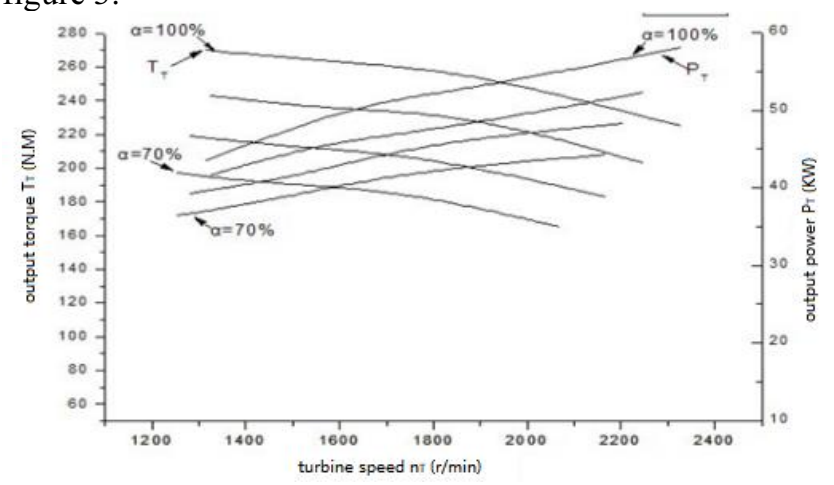

Figure 3. Output characteristics of engine and torque converter working together

\subsection{The Relationship Between Throttle Opening and Speed}

According to the relationship derived from equation 13, the relationship between throttle opening and speed can be obtained as shown in table 3 below.

TABLE III. THE RELATIONSHIP BETWEEN THROTTLE OPENING AND SPEED

\begin{tabular}{|c|c|c|c|c|c|c|c|c|c|c|c|c|}
\hline & \multicolumn{12}{|c|}{ throttle opening } \\
\hline \multirow{2}{*}{$\begin{array}{c}\text { Torque converter parameters } \\
\text { ratio }\end{array}$} & \multicolumn{4}{|c|}{50} & \multicolumn{4}{|c|}{60} & \multicolumn{4}{|c|}{70} \\
\hline & $i=0.75$ & $\mathrm{i}=0.85$ & $\mathrm{i}=0.9$ & $\mathrm{i}=0.95$ & $i=0.75$ & $\mathrm{i}=0.85$ & $\mathrm{i}=0.9$ & $\mathrm{i}=0.95$ & $\mathrm{i}=0.75$ & $\mathrm{i}=0.85$ & $\mathrm{i}=0.9$ & $\mathrm{i}=0.95$ \\
\hline Pump speed & 1521 & 1643 & 1748 & 2014 & 1637 & 1683 & 1796 & 2108 & 1674 & 1696 & 1927 & 2178 \\
\hline turbine speed & 1140 & 1396 & 1573 & 2028 & 1227 & 1430 & 1616 & 2097 & 1255 & 1441 & 1734 & 2169 \\
\hline pump torque & 153 & 155 & 151 & 149 & 168 & 172 & 168 & 166 & 187 & 191 & 187 & 183 \\
\hline turbine torque & 161 & 155 & 151 & 134 & 177 & 172 & 168 & 149 & 197 & 191 & 187 & 165 \\
\hline Pump input power & 27.63 & 33.44 & 37.41 & 40.58 & 32.13 & 36.71 & 40.57 & 45.18 & 39.02 & 42.68 & 45.68 & 51.28 \\
\hline turbine output power & 23.54 & 29.76 & 32.65 & 37.12 & 28.94 & 31.54 & 36.15 & 41.66 & 36.41 & 38.21 & 42.06 & 44.31 \\
\hline & \multicolumn{12}{|c|}{ throttle opening } \\
\hline Torque converter parameters & \multicolumn{4}{|c|}{80} & \multicolumn{4}{|c|}{90} & \multicolumn{4}{|c|}{100} \\
\hline ratio & $i=0.75$ & $\mathrm{i}=0.85$ & $\mathrm{i}=0.9$ & $\mathrm{i}=0.95$ & $\mathrm{i}=0.75$ & $\mathrm{i}=0.85$ & $\mathrm{i}=0.9$ & $\mathrm{i}=0.95$ & $i=0.75$ & $\mathrm{i}=0.85$ & $\mathrm{i}=0.9$ & $\mathrm{i}=0.95$ \\
\hline Pump speed & 1708 & 1784 & 1967 & 2224 & 1765 & 1847 & 2011 & 2367 & 1856 & 1926 & 2088 & 2453 \\
\hline turbine speed & 1281 & 1516 & 1770 & 2206 & 1323 & 1569 & 1809 & 2248 & 1377 & 1637 & 1879 & 2330 \\
\hline pump torque & 208 & 212 & 208 & 203 & 231 & 236 & 231 & 225 & 258 & 262 & 257 & 251 \\
\hline turbine torque & 219 & 212 & 208 & 183 & 243 & 236 & 231 & 203 & 270 & 262 & 257 & 225 \\
\hline Pump input power & 42.54 & 46.24 & 48.71 & 52.78 & 43.49 & 51.28 & 56.73 & 60.31 & 48.32 & 54.26 & 58.52 & 64.53 \\
\hline turbine output power & 39.28 & 41.43 & 45.68 & 48.36 & 41.58 & 45.88 & 47.43 & 52 & 43.49 & 50.93 & 52.67 & 58.07 \\
\hline
\end{tabular}




\subsection{Shift Rule Curve}

According to the torque characteristic diagram of the engine, the relation curve between torque and speed is converted into the relation curve between throttle opening and speed. At the same throttle opening $(\alpha)$, take the acceleration intersection point of two adjacent gears as the shift point. The shift point under different throttle opening is connected into a curve, then the shift curve of the adjacent two gears is obtained.

And so on, the shift curve of the vehicle can be obtained as shown in figure 4 , this is of great significance to the further study of vehicle performance.

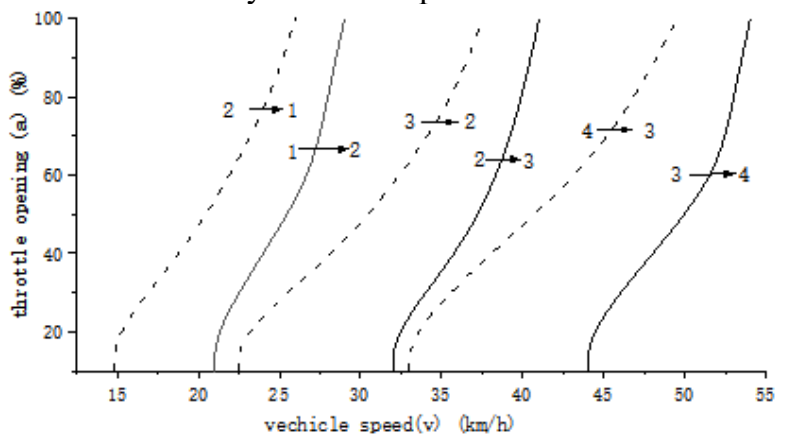

Figure 4. Best gear shifting rule at speed ratio $i=0.75$

\section{Curve Analysis of Gear Shift Rule}

In this paper, the shift rule diagram shown in Fig. 4 is obtained by using the two-parameter shift rule method, It gets into high gear early, which improves fuel economy. When the throttle is reduced, the shift speed difference is large, which ensures the vehicle to drive in the high speed gear, reduces the number of shift, and can make the vehicle obtain good comfort. When the throttle is increased, the shift speed difference is smaller, so that the vehicle has better power utilization and better power performance no matter it is to upgrade or downshift again. To sum up, this study on the shift rule of tractor is reasonable and conforms to the requirements of dynamic performance, economy and comfort.

\section{Conclusion}

In this paper, the relationship between speed and throttle opening is obtained by deducing the theoretical shift rule model, and the required speed for shifting at different throttle opening and different gear positions is calculated based on the relationship. Finally, the shift rule diagram under a certain speed ratio is made. The theory is applied to practice, and the vehicle can get a shift reference.Through the analysis of the shift pattern diagram, it can be known that the tractor can obtain better economic and dynamic performance under this pattern, which is of great significance to reduce fuel consumption and maximize dynamic performance in actual operation.

\section{REFERENCES}

[1] Zhong,G. Kong,Z. Yu,X. Xin,X. Chen. Shifting control of an automated mechanical transmission without using the clutch[J]. International Journal of Automotive Technology . 2012 (3).

[2] Zhang Linyue. Research on integrated shift control strategy for automatic transmission[C]..Abstracts of the 2015 2nd International Conference on Advanced Engineering Technology, 2015:60.

[3] Hebbale, K.V,Kao, C -K. Adaptive Control of Shifts in Automatic Transmissions. Proceedings of the 1995 ASME International Mechanical Engineering Congress and Exposition. 1995.

[4] Hiroshi Yamaguchi,Yasushi Narita,Hiroshi Takahashi,et al. Automatic Transmission Shift Schedule Control Using Fuzzy Logic. SAE Paper.

[5] Fei Meng,Gang Tao,Tao Zhang, Yihuai Hu,Peng Geng. Optimal shifting control strategy in inertia phase of an automatic transmission for automotive applications[J]. Mechanical Systems and Signal Processing, 2015,60-61. 